\title{
Work process of river family health teams from the perspective of Primary Care managers*
}

\author{
Processo de trabalho das equipes saúde da família fluviais \\ na ótica dos gestores da Atenção Primária
}

Proceso laboral de los equipos de salud de la familia fluviales bajo la óptica de los gestores de la Atención Primaria

How to cite this article:

Figueira MCS, Marques D, Vilela MFG, Bazílio J, Pereira JA, Silva EM. Work process of river family health teams from the perspective of Primary Care managers. Rev Esc Enferm USP. 2020;54:e03574. doi: https://doi.org/10.1590/S1980-220X2018027303574

\author{
Maura Cristiane e Silva Figueira ${ }^{1}$ \\ Dalvani Marques ${ }^{1}$ \\ Maria Filomena Gouveia Vilela ${ }^{1}$ \\ Jennifer Bazílio ${ }^{1}$ \\ Jéssica de Aquino Pereira ${ }^{1}$ \\ Eliete Maria Silva ${ }^{1}$

\footnotetext{
* Extracted from the thesis: "Processo de Trabalho das Estratégias Saúde da Família Fluviais e atributos da Atenção Primária em Saúde", Faculdade de Enfermagem, Universidade Estadual de Campinas, 2019.

${ }^{1}$ Universidade Estadual de Campinas, Faculdade de Enfermagem, Campinas, SP, Brazil.
}

\begin{abstract}
Objective: To analyze the work process carried out by the river family health strategy teams in a municipality in the Amazon region through the perception of the managers. Method: An evaluative study with a qualitative approach. Data were collected through semi-structured interviews with managers of Primary Healthcare, document analysis and participant observation of the work by content analysis. Results: Seven managers participated. Two thematic categories stood out: "Knowledge and practices in the work process of river teams" and "Reports of successful practice experiences". Conclusion: Integrated work and team autonomy are present in the work process; successful practices are encouraged, as well as the use of light and hard-light technologies.
\end{abstract}

\section{DESCRIPTORS}

Primary Care Nursing; Health Management; Family Health Strategy; Unified Health System. 


\section{INTRODUCTION}

Primary Health Care (PHC) in Brazil presents organizational differences in historical, social and among country contexts, being the subject of extensive discussions about existing models ${ }^{(1)}$.

As a proposal for reorienting the care model, the Community Health Agents Program (in Portuguese PACS) was created in 1991, and the first teams of the Family Health Program $(P S F)$ were structured in January 1994, incorporating and expanding the Community Health Agents actions. Family Health was initially structured as a program, but then changed its name to Strategy, aiming at restructuring municipal primary care services ${ }^{(2-3)}$.

In the early years, PACS and PSF were prioritized in regions with greater social vulnerability (north and northeast); however, federal funding for the programs stimulated their implementation and expansion throughout the national territory, especially in places with low population density and scarce services offer ${ }^{(4)}$.

According to territorial heterogeneity, the different contexts and specific characteristics of each location influence the implementation of healthcare arrangements in the Unified Health System (SUS), as socioeconomic and epidemiological profiles vary between regions of the country, the states of the same region and territories of the same municipality. However, the expansion of actions, services and the organization of $\mathrm{PHC}$ became the primary responsibility of municipal managers ${ }^{(1)}$ with the implementation of the SUS and the process of political-administrative decentralization, aiming at adapting to the local reality.

Therefore, a mobile health unit was set up in 2006 in the Amazon region by the municipalities on the banks of the Tapajós River in the western region of the state of Pará (Santarém, Belterra and Aveiro) with the support of a Dutch organization called 'Terre des hommes' functioning similarly to a traveling PSF in the river area. The unit was called "Abare" by the riverside community, which means "caring friend" in Tupi. Operational management was carried out by the Health and Happiness Project ( $P S A)$, a non-governmental organization (NGO) which operates in traditional Amazonian communities ${ }^{(5)}$.

Inspired by this initiative and in order to expand access and build models which could reach more inaccessible regions, the Ministry of Health instituted the River and Riverside Family Health Teams (ESFF) through Ordinance no. 2.191 of August 3,2010, whose implementation prioritized the care of the riverside population of the Legal Amazon and Pantanal Sul of Mato Grosso state. Next, Ordinance 2.488 of October 21, 2011 subsequently brought new criteria for implementing the teams ${ }^{(6)}$, while Ordinance no. 2.436 of 21 September $2017^{(7)}$ established the review of guidelines for the organization of PHC.

The Abare ship was accredited by the Ministry of Health as the first Basic River Health Unit (UBSF) in the country, being considered an intermunicipal health unit with staff in Santarém, Belterra and Aveiro, with an ESFF in each municipality integrating SUS services. Two more teams were subsequently established in another territory in Santarém in order to increase the access of the riverside populations from other regions of the municipality.

The teams develop their work activities in UBSF by boat or ship, and in the communities within the family health $\operatorname{area}^{(6-8)}$. The management of this ESFF care arrangement is the focus of this study, meaning the health work process in the Amazonian context from the perspective of PHC managers.

The health work process is used as the theoretical framework of this study, and is characterized as a set of coordinated actions performed by workers in which individuals, families and communities make up the object of work, and knowledge and procedures represent the instruments used to supply healthcare needs ${ }^{(9)}$.

Thus, the objective of this study was to analyze the work process performed by the river family health strategy teams in a municipality in the Amazon region considering the managers' perception.

\section{METHOD}

\section{STUDY DESIGN}

An evaluative study with a qualitative approach, with the following used as methodological instruments: document analysis, participant observation of the work and semi-structured interviews with PHC managers.

\section{STUDY SCENARIO}

The study scenario was the municipality of Santarém, located in the northern region of Brazil and west of the state of Pará. A population of 50,950 inhabitants who use small boats as a means of transport lives in the riverside regions of the municipality. Some of these communities are far from the urban center, about 20 hours by motor boat, and is constituted as the poorest region in the rural area. The communities in which the studied ESFF operate are located in the areas of the Tapajós and Arapiuns rivers, covering only a part of the local population with this healthcare assistance arrangement. According to the Brazilian Institute of Geography and Statistics (IBGE), the estimated population in 2018 totaled 302,667 inhabitants, of which $71 \%$ are in urban areas and $29 \%$ in rural areas. The demographic density is $12.87 \mathrm{inhab} . / \mathrm{km}^{2(10)}$.

\section{Population}

A semi-structured interviews with the seven PHC management actors who work with the ESFF was conducted. Managers were considered professionals who occupy positions which enable "control in the administration of resources, with instituted powers and which are therefore capable of operating resources to make sense", meaning to operationalize and implement certain public policies ${ }^{(11)}$. All of the managers had more than one year of work experience in PHC.

A meeting was held with the seven PHC managers to present the research project and clarify its operationalization. 
Individual contact to schedule the interviews and participant observation of the work was made, according to the consent of each manager and their time availability.

\section{Data Collection}

The available documents were the 2014-2017 municipal health plan, the annual management reports and schedules for 2016 and 2017, the ESFF implementation projects and reports on the units' structure and the developed actions. For the documentary analysis, one started from the initial question about how the implementation of river health teams in the municipality occurred. The social and political context in which the document was produced were considered, along with the authorship, understanding of the organization of the services and the interpretation and synthesis of the content.

A script for the semi-structured interviews was elaborated and divided in two parts: one with identification and professional training; and the second referring to the implementation procedures of the ESF, on the perception of the teams' work process, on the attributes of PHC and the specificities observed in the community work.

The interviews were conducted at the workplace of each manager, had an average duration of 60 minutes (minimum 37 and maximum 110 minutes), were recorded in audio and transcribed in full for speech recording and subsequent analysis. Participating observations were made at the health department and on trips to the areas, and were recorded in a field diary. Data collection took place from September to December 2017.

\section{DATA ANALYSIS AND PROCESSING}

The material was analyzed by reviewing the interview content, documentary analysis and participant observation. Content analysis for identifying empirical categories was performed through the following steps: pre-analysis, material exploration, processing the obtained results and interpretation $^{(12)}$.

The initial ideas were systematized according to the theoretical framework and identifiers were established to interpret the information in the pre-analysis. The material exploration consisted of "constructing coding operations", in which one considered "cutting the texts into recorded units", defining the frequency of appearance in the speeches, and "classifying and aggregating information into thematic categories" ${ }^{(12)}$. The material was subsequently processed and interpreted according to the work process framework.

Non-aprioristic categorization was implemented emerging from the context of the participants' responses ${ }^{(13)}$, with external content validation in discussion groups by experts in this research approach.

\section{ETHICAL ASPECTS}

This study was developed by the Nursing and Health Education and Practice Study and Research Group (GEPEPES) of the Nursing School of the Universidade Estadual de Campinas. The study was authorized by the
Municipal Health Secretariat of Santarém-PA and approved by the Unicamp Research Ethics Committee under opinion no. 2.079.984, of May 24, 2017.

The participants were duly informed about the research and signed the Informed Consent Form. The managers were identified by the perceived characteristics in their work, such as: Persistent, Enthusiastic, Confident, Altruistic, Diligent, Realistic and Responsible in order to ensure confidentiality of the participants. These characteristics were agreed upon and were suggested during the interview.

\section{RESULTS}

Seven managers participated. There are three ESFF in the municipality; one of them functions in the UBSF Abare $I$, which serves part of the Tapajós River region, while the other two function in the UBSF Abaré II, which covers part of the Arapiuns River region. These extensive rivers make up the hydrographic scenario of the municipality of Santarém, in the state of Pará, with many communities distributed along its banks and with difficult access to available public services.

The management positions of the participants in this study compose the organization chart of the Municipal Health Secretariat in the PHC axis, with the board of the Department of Primary Healthcare $(D A B)$, the general coordination of the ESFF, the coordination of the More Doctors (Mais Médicos) Program, directly linked to the DAB, and the Advisory Board of the Riparian Region, having the function of bringing management closer to the communities of the river area and the Coordination of each of the three ESFF. In total, seven health managers were interviewed.

Managers are characterized as being between 30 and 50 years old. Five are women, six are nurses, six professionals have a college degree and more than four years since their graduation; they have been in municipal management for two to eight years, working in PHC for over 10 years, and have expertise in areas related to public health. The employment bond is temporary service with a workload of 40 hours per week.

Two empirical categories were identified from the data analysis: "Knowledge and practices in the work process of river teams" and "Reports of successful practice experiences".

\section{CATEgory 1: KNOWLedGe AND PRACTICES IN THE WORK PROCESS OF RIVER TEAMS}

The study analyzes the work process of river teams from the perception of municipal managers. In the interviews the knowledge of the managers about how the teams work since its implementation, planning and implementation is noticed.

The managers report how teamwork began in the river regions:

Abare I began working in 2010 with the ESFF, it was inspired by the experience of the vessel used for service in riverside communities and river work in the municipality since 1996, before municipalization (Persistent).

Abaré II was created in 2012 with two teams for the Arapiuns region. It was initially in partnership with the NGO, but cur- 
rently the municipality assumes all costs with the health unit (Confident).

The understanding regarding the work's object was perceived among the managers. They cite the necessity of the people in the region for basic health services and report on efforts to improve healthcare for people living in the communities.

We are aware of the need and difficulty that these people of Tapajos and Arapiuns go through to get care here in the city, imagine in their community which is far away. These regions are very needy! (Altruistic).

Teams understand the need and difficulty these community members go through. It is a very poor population and the team experiences this when traveling to the areas (Confident).

About the agents in the work process, they emphasize integrated and teamwork and discuss the autonomy of the coordinators of each ESFF for decision-making with the team.

We observed that the manager of the ESFF has a certain degree of autonomy in streamlining the work process with the team (...), we give the support which is available for this to happen (Realistic).

The official management documents (municipal health plan and management report) and interviews of the Municipal Health Secretariat managers showed that the ESFF was prioritized as a way to reorganize the PHC in these regions of the municipality, aiming to provide access by the riverside population to services which were previously less frequent and/or non-existent. The municipality had 49 family health teams (57.41\% coverage) and 22 community health agents during the research period. Basic Health Units $(U B S)$ were created in communities far away from the city hall with professionals residing on site to provide care to users, four in the Tapajós riverside region and eight in Arapiuns. However, these are fixed units in more populous communities in regions with high demographic dispersion and difficulty of access.

There are places which only had the health unit (...) professional nurses were bired to live in the community. All this thinking about improving the access of the community and the periods when the river team could not be there (Responsible).

Most of the managers of this study and the workers of the municipality are nurses. The management considers nursing as a foundation in the practices performed in $\mathrm{PHC}$, because the UBS work with one nurse and the nursing technician in providing community care in the riverside regions.

The river mobile units did not perform the work in the region as scheduled during the data collection period, as they had technical and operational problems (maintenance of the structure and documentation); therefore, no trips were being made on these vessels to the areas.

In the period without the Abaré I and II structure, the Santarém team travels on chartered boats or on boats which normally travel to the communities. They take the materials necessary for the work and do it. By doing so, they generate production to report to the Ministry of Health (Altruist).

The teams are aware that they need to do the work in the communities and even without the river unit they use the basic units in some communities. They often make trips to work with priority groups (prenatal, hypertensive, diabetic, mental health, childcare) for health education in schools, home visits, medical and nursing consultations, and oral health prevention consultations.

We observed the concern of all managers interviewed with the work performed in an improvised manner, without the structured unit. The Persistent manager demonstrated distress that the unit was not owned by the municipality of Santarem. The same manager speaks enthusiastically of the team which does the work monthly and strives to do a good job (field work observation journal at the health department).

They report on trainings and improvements to equip staff for community work:

We also seek to not only equip our professionals with materials, we always schedule training (...) for example, when we bire a nurse for the interior, they spend some time in training, in the emergency sector, in obstetrics (...) in the family health units to see the programs (Responsible).

Regarding employment conditions, both ESFF managers and some workers have temporary employment, despite the long time in public service.

There is no possibility of rigorous standardization of services with strict protocols in the interior of the Amazon; teams need to be flexible to achieve the purpose of the work according to the needs and difficulties of the community. It is reported that the health services offered cause some confusion in communities, as some particular care initiatives still take place in inland regions such as churches, NGOs and autonomous groups. However, the team professionals clarify "what is the SUS" so that the community understands how the work process occurs.

We seek to clarify the communities from the municipality, what is the ESFF, and what is the SUS (Enthusiast).

The management reports that it analyzes the achievement of team objectives by the indicators and goals set and presented in the reports, as well as by the records and reports of actions by professionals and the community:

We track and identify the achievement of the objectives by the analyzed indicators such as vaccination coverage, prenatal monitoring, maternal and child mortality, which were very high, especially in Arapiuns. We also participate in meetings with community leaders which signal to us how the work is (Persistent).

The municipality has structured UBS in larger communities in the area of the ESFF to provide access and care continuity to community members in periods when the river unit is not in the area due to the long distances to the municipal headquarters. 
It is new for EESF areas to have a nurse in a UBS due to the dispersion of communities. This nurse gives support in the communities (Positive).

There are nurses who create bonds in the communities and who have been there for three, even four years and don't even want to leave. They are responsible and dedicated! (Diligent).

\section{CATEgory 2: Reports of SucCessful PRACTICE EXPERIENCES}

Meetings between teams are also encouraged and held frequently so they can share experiences that provide learning to teams.

I believe the municipality seeks to improve the service along with the team meeting more often to discuss work processes. The team gathers to do work planning and evaluation, checking the indicators to work. The More Doctors program physician is more integrated with the team (Enthusiast).

The teams had the first PHC meeting working on motivational teamwork themes, exchanging experiences to present their successful work and also what didn't work to share with others (Realistic).

Successful practices are cited by managers as an example of team autonomy to carry out the work and to achieve the teamwork goals.

Nurses create dynamics for work to be more fun and enjoyable. They work with puppets, they wear clown costumes. They work with the ludic! We encourage teams to be more dynamic (...), because the work goes far beyond curative actions (Realistic).

\section{DISCUSSION}

In the context of the ESFF, one highlights the object, the agents, the instruments and the purpose of the work through managers' perceptions about the work process of the river teams.

The health work process comprises several studies over many years which discuss and highlight its importance ${ }^{(11,14-18)}$, being used as a reference for the discussion of this study.

Managers of health services stand out as primordial in constructing management models which can participate in health production, in addition to contribute to training people who have projects that are responsible for developing care models articulated with SUS principles ${ }^{(19)}$.

Generally speaking, the health sector's object of work is human health needs; therefore, the raw material is that by which the workers' action is performed, and this object exists from the perspective of the worker together with the user and their purpose is to transform reality, and the managers are responsible for providing the means for this, so that together with the worker they can achieve their goals. This relationship is established in the worker meeting with the user, which is defined as "live work in action"(20).

Understanding the teams' work object and the health needs are highlighted by the managers, as well as the poor conditions and difficulties in the access to public goods and services by the users they serve. They also highlight the autonomy of the teams in carrying out the work, because knowledge of the territories and the daily life of the communities facilitates structuring the service flows.

In health services, "despite the adoption of practices which focus on prescriptive, bureaucratic acts and a high consumption of procedures, health work enables workers to operate with a certain degree of freedom and autonomy"(19). Because of this autonomy, socially committed workers adapt the available models, providing links with the communities in which they work, such as at ESFF, according to their reality and needs. They convert "norms and institutional designs into concrete acts and practices”, producing social reality, which means "even the strategy organized by norms, protocols and programs are the subjects inserted in it which shape the institutional design and its flows"(19).

The workers operate light technologies at all times and guide the use of other technologies. As stated by the managers, there is no possibility of rigidity in the instituted protocols in the interior of the Amazon, nor would it be desirable. If practices are predominantly guided by routines and protocols - although these are necessary for work organization - there is a risk of hardening, rigidity, formality in such a way as to limit spontaneous and creative action, emphasizing hard technologies and dead work ${ }^{(21)}$.

The temporary work contracts for both management and teams can be a hindering factor, as there is the possibility of work discontinuity due to the weakness in the employment bond. In a study conducted in the southeastern region, the managers cited the fragile employment bonds and the low remuneration paid by the municipalities as obstacles to job management ${ }^{(4)}$.

Managers report on the necessity of communities for health services and the effort and sensitivity of teams to develop work to meet both their needs and their satisfaction as a human being. Regarding the agents and their objects, a study ${ }^{(22)}$ highlights that every work process accomplishes the "existential and social objectives of the subjects" involved in it, which may or may not be clear to them. This moment is considered privileged for exercising capacities, and the possibility of realizing these individualities also becomes an objective.

Concerning the implications of performing services with results for health planning, it can be highlighted that: "the availability of inputs and equipment at the UBS, associated with $\mathrm{PHC}$ performance, reveals the importance of adequate financing and logistics for the quality of the ESF, as well as the formation of teams on the theme of family health" ${ }^{(23)}$. This factor influences the professional capacity to understand people's health needs and to be aware of resolving problems together with them.

In addition to structural and human resources problems, service organization, team management and professional practice suffer from inadequate provision of actions and services, difficulties related to the poor process of vocational training, precarious service infrastructure and employment bonds, and poor remuneration practice ${ }^{(4,24)}$.

An indicators' analysis is reported to evaluate achieving the objectives of the work, such as vaccination coverage, 
mortality rate and disease reporting; however, one emphasizes the understanding that the subjective issues of feelings, user, team and community satisfaction need to be stimulated more $^{(25)}$. User satisfaction allows us to readjust the organization, planning and management decision processes, as well as to monitor the work processes of professionals ${ }^{(25-26)}$. Thus, the dialogue to strengthen the subjects also stands out, pointing to the urgency of reaching the "art of dialogue in the care practices in public health", being useful for projects which aim to evaluate policies and public services by "inserting the user's perspective, considering their potential and ability to vocalize limits and potentialities"(26).

The results are corroborated by a study which states that "it is a major management challenge, since health intervention depends on the construction of relationships, the configuration of networks which cannot be answered by normalizing the work process" ${ }^{(19)}$. It is a dynamic process which depends on the encounter between workers and users in their life context and their interactions with the instruments, object and purposes to materialize healthcare according to their needs.

Discussions on health work technologies take place systematically, first distinguishing between technologies characterized by "work machines and instruments and those of technical knowledge", having been called "material technologies" and "non-material technologies"(14). This characterization stood out for establishing knowledge as a technology and highlighting social subjects, workers and users as holders of knowledge, which may improve the care provided. This knowledge is highlighted in this study by reporting that professionals are not only "provided" with material instruments, but also with various knowledge to improve their work in communities.

The managers stated that light technologies ${ }^{(11)}$ are the most encouraged to be used by teams, and assumed that it is widely used in their work process in PHC management.

The managers emphasize the work sharing between the teams and the experience reports to reach the health objectives through meetings with this purpose. One agrees that the uniqueness of the actors in the health work process should be considered and the interaction between these subjects depends on the potentialities provided by the meetings held by the health services. From this, "ensuring comprehensiveness in the intersubjectivity created in the multiple meetings which health services provide is a challenge of organizational practices, in which the reinvention of the work process must always be a point of reference"(27).

In addition, there is evidence that the possibility of building projects with positive impacts on health problems is established through the meetings between health workers and users ${ }^{(15)}$. For this reason, it is essential to use innovative means and work strategies which favor sharing experiences, the bond, involvement and the co-participation of these active subjects in the health production process.

Collective work is considered a "fundamental condition for operationalizing shared health management". "Freedom, creativity and autonomy in the work process of health professionals" should always be encouraged so that the process can flow to achieve the goals ${ }^{(28)}$.

As limitations, the scarcity of studies on the context of riverside populations for discussion, emphasizing the need for new approaches on the theme of river family healthcare.

\section{CONCLUSION}

The work process of the ESFF is complex and unique; from the perspective of managers, the way it can be organized cannot be done in a standardized, rigid way, and its planning cannot take place without the participation of communities. It is a flexible dynamic that can be modified according to the identified needs. Teams are encouraged to be autonomous in the work process, using creative, successful approaches, prioritizing light and hard technologies.

There may be the possibility of change processes due to the interviewed managers' acting and reporting, as there is the encouragement of teamwork by more autonomous professionals in the decisions and performance of work, in the redefinition of the work process and concern about existing working conditions. These characteristics of the manager's work provide the building of a manager-worker bond and favor relationships focused on improving the work process.

This study strengthens the statement that improving the quality of services needs to be discussed with health professionals and their users for planning, organization, decision-making, conduct and care flows review, aiming at reaching objectives which meet the health needs of communities. It is noteworthy that listening, welcoming, dialogue, bonding, and empathy need to be inserted in relationships so that they can strengthen and enhance the work processes of the teams.

There are many challenges in the work process of the ESFF, because such an arrangement presents peculiarities which are difficult to resolve such as the long distances between the communities of the territory; however, facing challenges through successful strategies is fundamental to strengthen primary care in municipalities with this reality from the perspective of organizing a health system that attains the SUS principles of universality, equity and the comprehensiveness of health care in the Amazon region as a whole, especially the riverside populations.

\section{RESUMO}

Objetivo: Analisar o processo de trabalho realizado pelas equipes das estratégias de saúde da família fluviais em município da região amazônica por meio da percepção dos gestores. Método: Estudo avaliativo com abordagem qualitativa. Os dados foram coletados por meio de entrevistas semiestruturadas com gestores da Atenção Primária em Saúde, análise documental e observação participante do trabalho com análise do conteúdo. Resultados: Participaram sete gestores. Destacam-se duas categorias temáticas: "Saberes e práticas no processo de trabalho das equipes fluviais" e "Relatos de experiências de práticas exitosas". Conclusão: O trabalho integrado e a autonomia das equipes estão presentes no processo de trabalho; práticas exitosas são incentivadas, bem como a utilização de tecnologias leves e leves-duras. 


\section{DESCRITORES}

Enfermagem de Atenção Primária; Gestão em Saúde; Atenção Primária à Saúde; Estratégia Saúde da Família; Sistema Único de Saúde.

\section{RESUMEN}

Objetivo: Analizar el proceso laboral llevado a cabo por los equipos de las estrategias de salud de la familia fluviales en municipio de la región amazónica mediante la percepción de los gestores. Método: Estudio evaluativo con abordaje cualitativo. Se recogieron los datos mediante entrevistas semiestructuradas con gestores de la Atención Primaria de Salud, análisis documental y observación participante del trabajo con análisis de contenido. Resultados: Participaron siete gestores. Se destacan dos categorías temáticas: "Saberes y prácticas en el proceso laboral de los equipos fluviales" y "Relatos de experiencias de prácticas exitosas”. Conclusión: El trabajo integrado y la autonomía de los equipos están presentes en el proceso laboral; se incentivan las prácticas exitosas, así como la utilización de tecnologías ligeras y ligeras duras.

\section{DESCRIPTORES}

Enfermería de Atención Primaria; Gestión en Salud; Estrategia de Salud Familiar; Sistema Único de Salud.

\section{REFERENCES}

1. Souza ROA, Machado CV, Noronha MF. Desafios da Gestão Municipal de Atenção em Saúde no Brasil: um estudo de caso. Rev APS [internet]. 2015 [citado 2018 jun. 14];18(2):166-79. Disponível em: https://aps.ufjf.emnuvens.com.br/aps/article/viewFile 2476/875

2. Brasil. Ministério da Saúde. Portaria n. 648, de 28 de março de 2006. Aprova a Política Nacional de Atenção Básica, estabelecendo a revisão de diretrizes e normas para a organização da Atenção Básica para o Programa Saúde da Família (PSF) e o Programa Agentes Comunitários de Saúde (PACS) [Internet]. Brasília; 2006 [citado 2018 Mar. 25]. Disponível em: http://189.28.128.100/dab/docs/legislacao/ portaria_648_28_03_2006.pdf

3. Paim J, Travassos C, Almeida C, Bahia L, Macinko J. The Brazilian health system: advances, and challenges. Lancet. 2011;377(9779):177897. DOI: https://doi.org/10.1016/S0140-6736(11)60054-8

4. Magnago C, Pierantoni CR. Difficulties and confronting strategies regarding the work management in the Family Health Strategy, in the perspective of local managers: the experience of the municipalities of Rio de Janeiro (RJ) and Duque de Caxias (RJ). Saúde Debate. 2015;39(104):9-17. DOI: http://dx.doi.org/10.1590/0103-110420151040194

5. Bernardes DCA, Oliveira FPA. Projeto Saúde \& Alegria: educação em saúde para melhor qualidade de vida. Rev Saúde Desenvolv [Internet]. 2012 [citado 2018 ago. 10];1(2):8-27. Disponível em: https://www.uninter.com/revistasaude/index.php/saudeDesenvolvimento/ article/view/44

6. Brasil. Ministério da Saúde. Portaria n. 2.488, de 21 de outubro de 2011. Aprova a Política Nacional de Atenção Básica, estabelecendo a revisão de diretrizes e normas para a organização da Atenção Básica, para a Estratégia Saúde da Família (ESF) e o Programa de Agentes Comunitários de Saúde (PACS). [Internet]. Brasília; 2011 [citado 2018 jan. 18]. Disponível em: http://bvsms.saude.gov.br/bvs/saudelegis/ gm/2011/prt2488_21_10_2011.html

7. Brasil. Ministério da Saúde. Portaria n. 2.436, de 21 de setembro de 2017. Aprova a Política Nacional de Atenção Básica, estabelecendo a revisão de diretrizes para a organização da Atenção Básica, no âmbito do Sistema Único de Saúde (SUS) [Internet]. Brasília; 2017 [citado 2018 mar. 25]. Disponível em: http://bvsms.saude.gov.br/bvs/saudelegis/gm/2017/prt2436_22_09_2017.html

8. Brasil. Ministério da Saúde. Passo a passo das ações do Departamento de Atenção Básica [Internet]. Brasília; 2013 [citado 2018 mar. 25]. Disponível em: http://189.28.128.100/dab/docs/portaldab/documentos/passo_a_passo_dab.pdf

9. Mendes-Gonçalves RB. Prática de Saúde: processo de trabalho e necessidades. In: Ayres JR, Santos L, organizadores. Saúde, sociedade e história. São Paulo: Hucitec; 2017. p. 298-374.

10. Instituto Brasileiro de Geografia e Estatística. Estatísticas por cidade e estado [Internet]. Rio de Janeiro: IBGE; 2018 [citado 2017 maio 7 ]. Disponível em: https://www.ibge.gov.br/

11. Merhy EE. Em busca do tempo perdido: a micropolítica do trabalho vivo em saúde. In: Merhy EE, Onocko R, organizadores. Agir em saúde: um desafio para o público. São Paulo: Hucitec; 2007. p. 71-112.

12. Bardin L. Análise de conteúdo. Lisboa: Edições 70; 2016.

13. Campos CJG. Método de análise de conteúdo: ferramenta para a análise de dados qualitativos no campo da saúde. Rev Bras Enferm. 2004;57(5):611-14. DOI: http://dx.doi.org/10.1590/S0034-71672004000500019

14. Paim JS. Da teoria do processo de trabalho em saúde aos modelos de atenção. In: Ayres JR, Santos L, organizadores. Saúde, sociedade e história. São Paulo: Hucitec; 2017. p. 375-92.

15. Merhy EE. A reestruturação produtiva na saúde, a produção do cuidado e a cartografia do trabalho vivo em ato. São Paulo: Hucitec; 2002.

16. Shimizu HE, Alvão DCJ. O processo de trabalho na Estratégia Saúde da Família e suas repercussões no processo saúde-doença. Ciênc Saúde Coletiva. 2012;17(9):2405-14. DOI: http://dx.doi.org/10.1590/S1413-81232012000900021

17. Oliveira AKS, Bezerra IMP, Silva CC, Lima Neto EA, Silva ATMC. Alternative experiences rescuing knowledge for working processes in health. Rev Esc Enferm USP. 2012;46(4):953-9. DOI: http://dx.doi.org/10.1590/S0080-62342012000400024

18. Santos DS, Mishima SM, Merhy EE. Processo de trabalho na Estratégia de Saúde da Família: potencialidades da subjetividade do cuidado para reconfiguração do modelo de atenção. Ciênc Saúde Coletiva. 2017;1(1):23-41. DOI: http://dx.doi.org/10.1590/141381232018233.03102016

19. Sulti ADC, Lima RCD, Freitas PSS, Felsky CN, Galavote HS. O discurso dos gestores da Estratégia Saúde da Família sobre a tomada de decisão na gestão em saúde: desafio para o Sistema Único de Saúde. Saúde Debate. 2015;39(104):172-82. DOI: http://dx.doi. org/10.1590/0103-110420151040238

20. Merhy EE, Franco TB. Trabalho em saúde. In: Pereira IB, Lima JCF, organizadores. Dicionário da educação profissional em saúde. Rio de Janeiro; 2009. 
21. Seixas CT, Merhy EE, Baduy RS, Slomp Junior H. La integralidad desde la perspectiva del cuidado en salud: una experiencia del Sistema Único de Salud en Brasil. Salud Colectiva. 2016;12(1):113-23. DOI: 10.18294/sc.2016.874

22. Faria HP, Werneck MAF, Santos MA, Teixeira PF. O processo de trabalho em saúde [Internet]. Belo Horizonte: Faculdade de Medicina; 2009 [citado 2018 mar. 20];2(1):21-7. Disponível em: https://www.nescon.medicina.ufmg.br/biblioteca/imagem/1790.pdf

23. Turci MA, Lima-Costa MF, Macinko J. Influência de fatores estruturais e organizacionais no desempenho da Atenção Primária à Saúde em Belo Horizonte, Minas Gerais, Brasil, na avaliação de gestores e enfermeiros. Cad Saúde Pública. 2015;31(9):1941-52. DOI: http:// dx.doi.org/10.1590/0102-311X00132114

24. Facchini LA, Tomasi E, Dilélio AS. Quality of Primary Health Care in Brazil: advances, challenges and perspectives. Saúde Debate. 2018;42(1):208-23. DOI: 10.1590/0103-11042018S114.

25. Gomide MFS, Pinto IC, Bulgarelli AF, Santos ALP, Gallardo MPS. User satisfaction with primary health care: an analysis of access and care. Interface (Botucatu). 2018;22(65):387-98. DOI: http://dx.doi.org/10.1590/1807-57622016.0633

26. Arruda CAM, Bosi MLM. User's satisfaction of primary health care: a qualitative study in the Northeast of Brazil. Interface (Botucatu). 2017;21(61):321-32. DOI: http://dx.doi.org/10.1590/1807-57622015.0479

27. Carnut L. Care, integrality and primary care: essential articulation to reflect on the health sector in Brazil. Saúde Debate. 2017;41(115):117786. DOI: https://doi.org/10.1590/0103-1104201711515

28. Gomes FN, Lima RCD, Galavote HS, Andrade MAC. O agir cotidiano dos gestores da Estratégia Saúde da Família: possibilidades e desafios. Rev Bras Pesq Saúde. 2016;18(1):36-44. DOI: https://doi.org/10.21722/rbps.v18i1.15130 